Research Square
Preprints are preliminary reports that have not undergone peer review.

They should not be considered conclusive, used to inform clinical practice, or referenced by the media as validated information.

\title{
Evaluation the energy production potential of aggressively invasive Prosopis juliflora Sw (Fabacea): An emerging threat in the Bundala Ramsar Wetland
}

W.A.R.T.W. Bandara ( $\sim$ rangika@kln.ac.lk)

University of Kelaniya Faculty of Science https://orcid.org/0000-0002-2080-9347

Oshadi Ruwanthika Ranasinghe

University of Kelaniya Faculty of Science

Richard Vlosky

Louisiana State University

\section{Research}

Keywords: Prosopis juliflora, Leucaena leucocephala Bundala Ramsar Wetland, biological invasive species, fuel oil, fuelwood

Posted Date: August 27th, 2020

DOI: https://doi.org/10.21203/rs.3.rs-55474/v2

License: () (i) This work is licensed under a Creative Commons Attribution 4.0 International License. Read Full License 


\section{Abstract}

Prosopis juliflora is an invasive plant species rapidly expanding in the Asian and African continents. Invasion of P. juliflora in Bundala Ramsar Wetland (BRW) in Sri Lanka has created a number of biodiversity and conservation issues. This study was conducted to assess the possibility to utilize this invasive plant as a fuel source for local industries. The moisture content, wood density, ash content, volatile matter, fixed carbon content, biomass/ash ration and calorific value of P. juliflora were measured and compared with Leucaena leucocephala, which is a widely used fuelwood source in Sri Lanka and elsewhere. P. juliflora, performed better than L. leucocephala for most of these parameters. Ash content was comparatively higher in P. juliflora than that of L. leucocephala; however, biomass to ash ratio of P. juliflora was significantly lower (at 0.05 level of significance) than that of L. leucocephala, suggesting its suitability as a fuelwood source. Further, the Fuel Value Index (FVI) of P. juliflora $(3,276)$ was slightly lower than that of L. leucocephala $(3,336)$, a non-significant difference. P. juliflora and L. leucocephala reached Fiber Saturation Point values within drying periods of 24 and 27 days, respectively. According to our estimates of energy properties, $1 \mathrm{Kg}$ of P. juliflora could be used to substitute $0.5 \mathrm{~L}$ of diesel and furnace oil as well as $5 \mathrm{kWh}$ ( 5 units) of electricity. As such, we recommend harvesting P. juliflora from BRW as a potential fuelwood energy source for local industries.

\section{Introduction}

Invasive plants are known to change community ecology attributes of ecosystems including species diversity, species richness, and species composition and abundance [1]. Prosopis juliflora (Fabaceae), native to Mexico, central and northern parts of South America [2] is a tree growing up to $15 \mathrm{~m}$ height. Europeans introduced this plant globally in the past 200 years as a drought resistant species and for soil conservation purposes. At present, $P$. juliflora has become an aggressive invasive species in its new habitats, outcompeting native species, and created a number of conservation problems in different parts of the world including Kenya, Tanzania, Northern Uganda, Australia, India and Sri Lanka [2, 3]. Invasive characteristics of P. juliflora include rapid growth, low nutrient requirements to thrive, ability to grow in water logged areas, an ability to withstand high salinity conditions, high seed production, a tendency to form impenetrable thickets, an ability to thrive in variable soil conditions, and foliage which is unpalatable to livestock [3]. Introduction and subsequent invasion of $P$. juliflora in Lake Baringo in Kenya has become a national level controversial issue. P. juliflora has invaded crop fields, grazing lands, wetlands and lakeshores in Kenya. Its invasion has reduced grazing territory for livestock and the value of wetlands for watering and dry season grazing [4] and also replaced native flora and fauna species in indigenous ecosystems [5,6].

In 1880, the British introduced P. juliflora to Bundala in Hambantota District, Southern Province in Sri Lanka. This area was designated a National Park on January $4^{\text {th }}, 1993$ (Gazette Notification No. 748/3), having originally been declared a Sanctuary on December $5^{\text {th }}, 1969$ (Gazette Notification No. 14,883). Bundala is the island's first Ramsar Wetland (BRW) and it was designated as a Wetland of International Importance at the time of Sri Lanka's ratification of the Ramsar Convention in October 1990. A Ramsar Site is a wetland site designated to be of international importance under the Ramsar Convention. The Ramsar Convention is an intergovernmental environmental treaty established in 1971 by the United Nations Educational, Scientific and Cultural Organization (UNESCO). P. juliflora is now considered as the major invasive species at BRW due to its negative impact on native biodiversity [7]. BRW has been severely threatened in the last decade due to the invasion of $P$. juliflora; in 2009 it was estimated that the species encompassed $60 \%$ of its land area. The IUCN has estimated that 10,000 ha in and around the park are now affected and $P$. juliflora has widely spread in the shore areas of the BRW, occupying a vast extent available for wading birds. Further, this species has destroyed certain habitats and reduced home ranges of mega fauna, including elephants [8].

P.juliflora has highly threatened not only faunal diversity but also floral diversity in BRW. Manilkara hexandra has been identified as a dominant canopy tree in dry forests of Sri Lanka with a very poor natural regeneration capacity. Recent studies carried out in BRW recorded that there has been a severe dying out of $M$. hexandra species and dead trees are mostly seen in proximity to lagoons and inland water bodies. The studies further revealed that $P$. juliflora has dominated those areas resulting in less plant diversity, and negatively influencing biological diversity in the area [9].

Relevant to damage caused by invasive plant species in protected lands and agricultural areas, there is no proper institutional and legal framework to manage Invasive Alien Species (IAS) in Sri Lanka. McNeely [10] suggested that producing energy from invasive plant species could be a solution to control IAS worldwide. P. juliflora has a fast-growing rate and ability to grow in a variety of soil conditions. It coppices very well and sprouts rapidly following harsh and repeated cutting, without any harmful effects on plant health [11]. These attributes make $P$. juliflora a good candidate for fuelwood in countries where it shows invasive characteristics [6].

The use of biomass especially for thermal energy in the industrial sector in Sri Lanka has been recognized in the country's Energy Sector Development Plan for 2015-2025. Several plant species including Gliricidia sepium, Acacia auriculiformis and Calliandra calothyrsus have been identified as common fuelwood species in Sri Lanka due to their high calorific values (4000-5000 kcal kg-1)[12]. Additional fuelwood species found in Sri Lanka are Eucalyptus grandis, Eucalyptus camaldulensis, Casuarina equisetifolia, Clusia rosea, Leucaena leucocephala and Paraserianthes falcataria [12]. Further, several species including Alstonia macrophylla and Acacia auriculiformis have been introduced by the Forest Department of Sri Lanka to fulfill timber and other wood requirements of the country $[12,13]$.

The present production of biomass for energy generation requirements is only adequate to fulfill $55 \%$ of the total energy demand of the country. The rest is fulfilled by hydropower and by imported fossil fuels. Therefore, there is a need to identify alternative energy sources including biomass where extraction would not contribute to land degradation, deforestation and biodiversity loss.

In this context, the use of $P$. juliflora in energy production may be a good option. However, studies in the region to evaluate the full energy profile of $P$. juliflora are lacking. Therefore, this study was conducted with the objective of estimating energy and mechanical properties of $P$. juliflora to understand its applicability and efficiency as a source of energy. Study outcomes would be helpful in controlling the spread of invasive $P$. juliflora while determining its potential as an alternative energy source to partially fulfill the thermal energy demand of local industries in the region. 


\section{Materials And Methods}

\subsection{Sampling area}

P. juliflora was sampled from BRW that lies in the south coast of Hambantota District, low country dry zone, Sri Lanka $\left(6^{\circ} 08^{\prime}-6^{\circ} 14^{\prime} \mathrm{N}, 81^{0} 08^{\prime}-81^{0} 18^{\prime} \mathrm{E}\right)$. The total area of BRW is 3,698 ha. The mean annual rainfall in the area ranges from $900 \mathrm{~mm}$ to $1300 \mathrm{~mm}$, with two peak rainfall periods during April-May and October-November. The mean annual temperature is about $27^{\circ} \mathrm{C}$ while relative humidity ranges between $76 \%$ and $81 \%$ [9].

BRW has diverse vegetation, which shows natural succession from low creeping plants to climax forests described as thorny, dry semi-evergreen and dry mixed evergreen. The forest canopy of the tropical semi-deciduous forest area of BRW consists of typical, native forest vegetation $M$. hexandra [9]. Canopy layers of other areas consist of species such as Salvadora persica, Limonia acidissima, Strychnos potatorum and Drypetes sepiaria. The lower tree layer consists of species such as Allophylus cobbe, Benkara malabarica, Capparis zeylanica, Erythroxylum monogynum, Memecylon umbellatum and Ochna lanceolata [14]. In addition, an array of vegetation occurs in low lying areas along Bundala Lagoon, as aquatic vegetation, salt marshes, mangroves, etc. Presently, the dry mixed evergreen forest area of BRW is dominated by invasive $P$. juliflora species. This invasion is more abundant along the lagoon as well as inland water bodies [9].

\subsection{Selection of sampling sites}

Sampling sites were selected using handheld GPS (Garmin eTrex Summit, Taipei/Taiwan).

\subsection{Sampling of P.juliflora and L. leucocephala}

All the $P$. juliflora individuals with Diameter Breast Height $(\mathrm{DBH})>5 \mathrm{~cm}$ in the sampling sites were considered for the study (Figure 1). Sixty individuals were categorized into different diameter classes; DBH class 01: $10 \mathrm{~cm}$ to $19.99 \mathrm{~cm}$; DBH class 02: $20 \mathrm{~cm}$ to $29.99 \mathrm{~cm}$ and; DBH class $03: 30 \mathrm{~cm}$ to $39.99 \mathrm{~cm}$. $L$. leucocephala is another widely used fuelwood species found in Hambantota District where $P$. juliflora is abundant. In order to compare the energy potential of $P$. juliflora with that of $L$. leucocephala, a site near BRW where $L$. leucocephala was abundant was selected. Optimum sample size to compare energy characteristics of $P$. julfiflora with those of L. leucocephala was determined according to Pearson [15]. Altogether 40 individuals of $P$. juliflora and 20 individuals of $L$. leucocephala were selected to obtain samples. GPS coordinates of the site were $81^{\circ} 16^{\prime} 41.526 " E$ and $6^{\circ} 12^{\prime} 20.537^{\prime \prime} \mathrm{N}$. Study sites of $P$. juliflora and L. leucocepahala are illustrated in Figure 2.

In order to extract samples to estimate fuelwood properties of $P$. juliflora, sample wood disks were cut at breast height from the 40 stems found in the study plot. The disks were packed in airtight polyethylene bags. Later, in the laboratory, $5 \mathrm{~cm} \times 5 \mathrm{~cm} \times 5 \mathrm{~cm}$ cubes were cut from the disks to test for fuelwood properties such as, moisture content, density, specific gravity, ash content, volatile matter content, fixed carbon content and biomass/ash ratio. An additional set of specimens was prepared from 20 trees of $L$.leucocephala for comparison of fuelwood characteristics with $P$. juliflora. All specimens were prepared in triplicate from each individual selected tree for both species.

\subsection{Drying profiles of sample specimens}

In addition to the previously mentioned disks that were cut from sample trees, another set of samples with dimensions of $18 \mathrm{~cm} \times 2 \mathrm{~cm} \times 2 \mathrm{~cm}$ was prepared from both species for the construction of drying profiles. These specimens were prepared within $24 \mathrm{~h}$ of sample extractions and each specimen was labeled and packed in airtight bags to avoid moisture loss.

2.5 Measurements and calculations

\subsubsection{Moisture content.}

The moisture content of P. juliflora was measured following the oven dry method [16].

\subsubsection{Wood density.}

Densities were determined using the volume and oven dry weight of samples. Volumes of the specimens were determined using the water displacement method as recommended in ASTM D2395-17.

\subsubsection{Specific gravity:}

Specific gravity was determined using the maximum moisture content method [17].

\subsubsection{Ash content and volatile matter:}

Ash content of each specimen was determined using the loss of ignition method [18]. The same samples used for moisture content testing were used to determine the percentage of volatile matter [19].

\subsubsection{Fixed carbon content:}

Fixed carbon content was determined by subtracting the total of volatile matter percentage and ash content percentage from 100 . Each data point of every parameter considered here was estimated by taking the average of three replicate samples [16]. 


\subsubsection{Biomass/ash ratio:}

The biomass/ash ratio of two species was determined by dividing oven dry weights of the samples by ash weights [20].

\subsubsection{Gross calorific values:}

Gross calorific value of each sample was determined according to ASTM D 5865 standard procedures.

\subsubsection{Fuelwood Value Index:}

FVI was calculated for each individual sample using calorific value, wood density, ash content and moisture content and applying Eq. (1) [21]. In the FVI index, ash content and moisture contents were given in ratios $\left(\mathrm{g} \mathrm{g}^{-1}\right)$, density was given in $\mathrm{g} \mathrm{cm}^{-3}$ and calorific value in $\mathrm{kJ} \mathrm{g}^{-1}$.

Equation (1)

$\mathrm{FVI}=\frac{\text { Calorific value }(\mathrm{kJ} g-1) \times \text { Density }(\mathrm{g} \mathrm{cm}-3)}{\text { Ash content }(\mathrm{g} g-1) \times \text { Moisture content }(\mathrm{g} g-1)}$

Calorific value data and density data of diesel and furnace oil were provided by the Ceylon Petroleum Corporation [22]. The number of liters of diesel and furnace oil that can be replaced by $1 \mathrm{~kg}$ of each fuelwood type was calculated by the authors.

\subsection{Statistical analysis}

The values for moisture content, density, specific gravity, ash content, volatile matter and fixed carbon content of each DBH class were subjected to one-way Analysis of Variance (ANOVA) using MINITAB ${ }^{\circledR}$ Version 14 statistical software after following the Anderson Darling Normality test. Percentage values of moisture content, ash content, volatile matter content and fixed carbon contents were subjected to arcsine transformation before doing Normality test. Tukey's pair-wise comparison was carried out to test for significant differences between the three DBH classes for each measured parameter. In addition, comparisons of energy potential of $P$. juliflora and $L$. leucocephala were subjected to the same statistical tests.

\section{Results}

3.1 Comparison of fuelwood characteristics of $P$. juliflora in pre-selected diameter classes

Comparison of moisture content, density, specific gravity, ash content (\%), volatile matter content (\%) and fixed carbon content (\%) among three diameter classes $(10-19.99 \mathrm{~cm}, 20.00-29.99 \mathrm{~cm}$ and $30.00-39.99 \mathrm{~cm}$ ), resulted in significant differences (at 0.05 level of significance) in volatile matter content (higher values) and fixed carbon content (lower values) for diameter class $3(30 \mathrm{~cm}-39.99 \mathrm{~cm})$ relative to the other two diameter classes. All other parameters tested did not show significant differences (at 0.05 level of significance) between the three diameter classes (Table 1).

For each characteristic, mean value indicated by different superscript letters are significantly different from each other ( $p<0.05)$. Since there was no significant difference (at 0.05 level of significance) among three diameter classes of $P$. juliflora in terms of its energy performance values obtained, all the diameter classes were pooled for further analysis. When comparing energy properties (moisture content, density, specific gravity, ash content (\%), volatile matter content $(\%)$ and fixed carbon content (\%), biomass/ash ratio and gross calorific value or GCV of P. juliflora and L. leucocephala, other than ash content, all other tested parameters had higher (better) values in P. juliflora compared to $L$. leucocephala. Although ash content of $P$. juliflora (1.70\%) was slightly higher than that of $L$. leucocephala (1.20\%), biomass to ash ratio of $P$. juliflora was greatly lower than that of $L$. leucocephala which indicates a positive trait for use as fuelwood. However, considering overall performance estimated using FVI, L. leucocephala has a slightly higher value (3336) than P. juliflora (3276) (Table 2).

There are nine commonly used fuelwood species in Sri Lanka including L. leucocephala [12]. When considering calorific value as a measure to evaluate energy performance of fuelwood species, values range from $13.025 \mathrm{~kJ} \mathrm{~g}^{-1}$ to $20.724 \mathrm{~kJ} \mathrm{~g}^{-1}$. Calorific values of $P$. juliflora and $L$. leucocephala lie in this range. Calorific values of $P$. juliflora are closer to the most common fuelwood species in Sri Lanka, G. sepium. Estimated GCV values for $P$. julflora and $L$. leucocephala were compared with calorific values of commonly used fuelwood species in Sri Lanka (Figure 3).

\subsection{Drying profile for $P$. juliflora and L. leucocephala}

The drying profile of $P$. juliflora and L. leucocephala, constructed for a period of 35 days of drying, is shown in Figure 4 . The initial drying rate descended with the number of drying days and then reached a plateau at about $15 \%-20 \%$ moisture content. The moisture content at the plateau was considered to be the Fiber Saturation Point (FSP) for the species' samples. FSP is the moisture content at which the cell wall is saturated with bound water and at which no free water is present. L. leucocephala reached FSP in $27 \mathrm{~d}$ while $P$. juliflora took $24 \mathrm{~d}$ to reach FSP.

3.3 Estimating the units of fossil fuel $(\mathrm{L})$ and electricity $(\mathrm{kWh})$ that can be replaced by a $\mathrm{kg}$ of $P$. juliflora and L. leucocephala wood When comparing the performance of P. juliflora with L. leucocephala, results are similar for both species (Table 3).

These were calculated based on gross calorific value of diesel, furnace oil, and $1 \mathrm{kWh}$ of electricity compared to gross calorific value of $P$. juliflora and $L$. leucocephala

The calculation process used was as follows, with diesel as an example: 
- Calorific value of diesel $=43,961 \mathrm{~kJ} \mathrm{kg-1}$

- Burning $1 \mathrm{~kg}$ of diesel produces $43,961 \mathrm{~kJ}$ of energy

- Calorific value of juliflora $=18,666 \mathrm{~kJ} \mathrm{~kg}^{-1}$

- Burning $0.424 \mathrm{~kg}$ of juliflora wood is required to produce $43,961 \mathrm{~kJ}$ of diesel

- Therefore, $1 \mathrm{~kg}$ of diesel can be replaced by $0.424 \mathrm{~kg}$ of wood

- $1 \mathrm{~L}=0.001 \mathrm{~m}^{3}$

- Maximum density of diesel at $15^{0} \mathrm{C} 860 \mathrm{~kg} \mathrm{~m}^{-3}$

- Therefore $0.424 \mathrm{~kg}=0.5 \mathrm{~L}$

- $5 \mathrm{~L}$ of diesel can be replaced by $1 \mathrm{~kg}$ of $P$. juliflora wood.

The same calculations were followed for each fossil fuel type and wood type (P. juliflora and L. leucocephala) (Table 3).

3.4 Prediction of units of fossil fuels and electricity that can be replaced by an average $P$. juliflora tree

The average DBH of $P$. juliflora in the study site was $23.16 \mathrm{~cm}$. Fuelwood yield produced by an average sized individual was estimated using Eq. (2) [23,24].

\section{Equation (2)}

$Y=2.10+5.08 X$

$\mathrm{Y}=$ Fuelwood yield $(\mathrm{kg})$

$\mathrm{X}=\mathrm{DBH}(\mathrm{cm})$

- According to Eq. (2), the predicted yield of an average sized individual $=119.74 \mathrm{~kg}$

- Amount of diesel replaced by the yield $=$ about $60 \mathrm{~L}$

- Amount of furnace oil replaced by the yield $=$ about $54 \mathrm{~L}$

- Units of electricity replaced by the yield $=620$ Units $=620 \mathrm{kWh}$

There were no significant differences (at 0.05 level of significance) among three DBH classes (10.00-19.99 cm, 20.00-29.99 cm, $30.00-39.99 \mathrm{~cm})$ of $P$. juliflora for the energy characteristics of moisture content, ash content, density and calorific value. Therefore, individuals of any diameter of $P$. juliflora could be harvested for energy production. When considering calorific value as a measure of evaluating fuelwood, $P$. juliflora falls in the range of most common types of fuelwood species used in Sri Lanka. Although there were significant differences (at 0.05 level of significance) between some energy characteristics, when considering overall performance, there is no significant difference (at 0.05 level of significance) between $P$. juliflora and $L$. leucocephala.

Both P.juliflora and L. leucocephala should be air dried for a period of one month before utilizing it as a fuelwood. P. juliflora and L. leucocephala wood can be used to replace fossil fuel (diesel and furnace oil), and electricity to a certain extent. An average size (DBH $23.16 \mathrm{~cm}$ ) $P$. juliflora individual can replace $60 \mathrm{~L}$ of fossil fuel and $620 \mathrm{kWh}$ of electricity. Therefore, $P$. juliffora can be utilized as an alternative source of energy as a partial solution to foreign oil dependency in Sri Lanka.

\section{Discussion}

Overall fuelwood performance measures, such as moisture content, specific gravity, ash content, volatile matter and fixed carbon content of $P$. juliflora were comparable with that of $L$. leucocephala, which is a widely used fuelwood species in Sri Lanka and other countries. P. juliflora samples had significantly lower (at 0.05 level of significance) moisture content than L. leucocephala samples; higher moisture content decreases wood calorific value [25]. In addition, species with low moisture content are favored as fuelwood due to their superior combustion characteristics and higher Net Calorific Values (NCVs) [18, 26].

As trees with higher wood density contain more heat per unit volume [27], P. juliflora, with a significantly higher wood density, could be considered as a better option in energy production than $L$. leucocephala. Specific gravity of $P$. juliflora was found to be significantly higher (at 0.05 level of significance) than that of $L$. leucocephala, supporting the findings of Chavan et al. [25]. Ash content of P. juliflora (2.25\%) was slightly higher than that of $L$. leucocephala (1.5\%), as reported by Chavan et al. [25]. Ash content values of $P$. juliflora and $L$. leucocephala were in the same range when compared with other tropical fuelwood species including Acacia nilotica (2.8\%), A. leucophloea (2.7\%), Prosopis cineraria (2.5\%), Tectona grandis (2.2 \%), Cassia fistula (1.6\%), Butea monosperma $(1.8 \%)$ and Sterculia urens $(1.4 \%)([18,28]$. P. juliflora has significantly lower (at 0.05 level of significance) volatile matter content compared to L.leucocephala (at 0.05 level of significance). Typically, volatile matter content of biomass will volatilize and burn as a gas [27]. Results of a study by Oduor and Githiomi [29] support the volatile matter content obtained for $P$. juliflora in the present study. P. juliflora has significantly higher (at 0.05 level of significance) fixed carbon 
content (20.00) than L. leucocephala (14.56). Fixed carbon content is determined by the volatile matter content and ash content of the species. A study by Pasiecznik et al [11] suggested that $P$. juliflora has high heat of combustion due to a high amount of carbon content.

Natural air-drying is the most reliable method that could be used to dry fuelwood in a tropical country like Sri Lanka due to prevailing dry and sunny conditions. In addition, fuelwood pieces have to be small enough to facilitate rapid drying [30]. In the present study, initial drying rate was descending with the number of drying days and FSP was achieved by P. juliflora in $24 \mathrm{~d}$ and L. leucocephala within $27 \mathrm{~d}$. The findings of the present study are supported by a study conducted by Groves and Chivuya [30] for four Australian tropical species. However, in the Australian study, the four species reached FSP of $28 \%-30 \%$ within eight days of drying. Variations of results observed in the two studies may be due to climatic conditions in two regions, including air temperature, humidity, rainfall and evaporation. The FSP is generally considered as $28 \%$ to $30 \%$ moisture content. It is not a fixed point and it may vary in different species from $19 \%$ to $30 \%$ [31]. Both species in the present study achieved FSP in the $15 \%-20 \%$ range for moisture content. The FSP values could be affected by the drying rate of the species. Hence in the natural air-drying process it is practical to dry both species for a period of one month in order to achieve efficient drying, thereby increasing fuelwood performance including NCVs of the species due to less moisture content.

Biomass/ash ratio of $P$. juliflora (57.70 \pm 7.00$)$ did not significantly vary (at 0.05 level of significance) with that of $L$. leucocephala (62.80 \pm 8.80$)$ and is in the comparable range with the other species, Mangifera indica (72.7), Morchella tomentosa (69.3), Acacia leucophloea (50.3) and Acacia nilotica (46.7)[18]. According to the present study, there is no significant difference (at 0.05 level of significance) between calorific values of $P$. juliflora (18.66) and $L$. leucocephala (18.35). In contrast, a study by Chavan et al. [25] indicates that the calorific value of $P$. juliflora $(20.82 \mathrm{~kJ} / \mathrm{g})$ was higher than that of $L$. leucocephala $(18.56 \mathrm{~kJ} / \mathrm{g})$. According to a study carried out in India by Pasiecznik and Felker [11], the calorific value of $P$. juliflora was $17.6 \mathrm{~kJ}$ Kg ${ }^{-1}$. Comparison of calorific values of $P$. juliflora with $L$. leucocephala and other commonly used fuelwood species in Sri Lanka suggests that $P$. juliflora could be utilized as an alternative fuelwood species in Sri Lanka. The fact that this is an invasive species warrants additional research into its use as fuelwood.

The current study shows that there is no statistically significant difference (at 0.05 level of significance) between the $\mathrm{FVI}$ of $P$. julilfora (3,276 \pm 274$)$ and that of $L$. leucocephala $(3,336 \pm 389)$. Therefore, FVI findings suggest that although there are significant differences (at 0.05 level of significance) between $P$. juliflora and $L$. leucocephala for a few fuelwood characteristics, overall performance is better than or equal to $L$. leucocephala. Previous studies [20] showed that high calorific value, high wood density, low ash percentage, low wood moisture and a high biomass/ash ratio are highly desirable fuelwood properties. Fuelwood species with such properties have FVI over 2,000 and this includes $P$. juliflora (FVI value of 3,276 ).

According to Siri et al. [32], there is a considerable preference for $P$. juliflora due to its high heat capacity and availability. Industries which depend on fuelwood to fulfill their energy requirements are willing to use $P$. juliflora but they do not have access to obtain $P$. juliflora in BRW. According to the results, there were no significant differences ((at 0.05 level of significance) among different DBH classes of $P$. juliflora for energy characteristics, such as moisture content, density, specific gravity and ash content. Complying with this result, Dias and Marenco [33] have indicated that there is no significant difference of moisture content and wood density of certain species with $\mathrm{DBH}[34,35]$. That might be the possible reason for the current finding of no difference between densities in DBH classes. Results of specific gravity tests in three DBH classes in the present study support results found by Navarro et al. [36] where the diameter of tropical species does not significantly affect nor is a determining factor of specific gravity. As such, P. juliflora could be harvested from BRW for fulfilling energy requirements in the area without considering different sizes or DBH classes in terms of energy performance.

Salt cedar and Russian olive are two species which show invasive characteristics including vigorous resprout after cutting. Both species have extensive root systems as they are sporophytes, hence complete removal of trees with the root system is necessary to prevent regrowth [37]. Since mesquite is generally similar in structure to salt cedar and Russian olive [37], cutting and uprooting could be considered as a potential solution in controlling the growth of mesquite, $P$. juliflora. Wood pellets, bio oil, and charcoal are promising sources of energy and P.juliflora can also be utilized to extract chemicals such as resins and polymers. Further testing is recommended on such aspects of using $P$. juliflora.

Past studies have shown that managing $P$. juliflora infested lands for charcoal production with a four-year harvest cycle is more profitable than using $P$. juliflora pods for flour production. However, authors have recommended vigilant regulation in using $P$. juliflora to avoid exploitation of native plants. Management measures are necessary to prevent charcoal production sites from becoming potential seed sources [38]

A study conducted by Walter and Armstrong [39] concluded that there is a great potential for the usage of $P$. juliflora as a source for energy production. Further, the production of charcoal from $P$. juliflora could be identified as an additional income opportunity. Additionally, reclaiming degraded lands and remediating heavy metal-contaminated soils, and feeding lifestock can be identified as other benefits that can be obtained from $P$. juliflora [39].

Therefore, this study implies that the replacement of fossil fuel and electricity usage with $P$. juliflora fuelwood in certain industries in Hambantota region could be considered as a viable option in terms of economic and environmental sustainability for a developing country like Sri Lanka. At the same time, with the intervention of relevant government and non-governmental institutions, cutting and uprooting trees for energy would be an ideal solution to control aggressive invasiveness of $P$. juliflora on the biodiversity of BMR.

\section{Conclusion}

There were no significant differences among three DBH classes $(10.00-19.99 \mathrm{~cm}, 20.00-29.99 \mathrm{~cm}, 30.00-39.99 \mathrm{~cm})$ of $P$. juliflora for certain energy characteristics including moisture content, ash content, density and calorific value. Therefore, individuals of any diameter of $P$. juliflora could be harvested for energy production process. When considering calorific value as a measure of evaluating fuel wood, $P$. juliflora lie in the range of most common types of fuel wood species used in Sri Lanka. Although there were significant differences among certain energy characteristics, when considering overall performances, there is no significant difference between P. juliflora and L.leucocephala. Both $P$. juliflora and L.leucocephala should be air dried for a period of a month before utilizing it as a fuel wood. P. juliflora and L.leucocephala wood can be used to replace fossil fuel (diesel and furnace oil) and electricity to a certain extent. 
Average size $(\mathrm{DBH} 23.16 \mathrm{~cm})$ P. juliflora individual can replace $60 \mathrm{I}$ fossil fuel and $620 \mathrm{kWh}$ electricity units in kWh. Therefore, $P$. juliflora can be utilized as an alternative source of energy as a partial solution to foreign oil dependency for local industries in Sri Lanka.

\section{Declarations}

\section{Availability of data and materials}

All data generated or analyzed during this study can be provided as a separate file in machine readable format upon request.

\section{Competing interests}

The authors declare they have no competing interests.

\section{Funding}

This work was supported by the Sustainable Energy Authority of Sri Lanka.

\section{Authors' contributions}

W.A.R.T.W.Bandara provided the research idea and design and contributed in data collection and writing, O.R.Ranasinghe contributed in data collection, processing and writing and R.Vlosky contributed in research idea generation and writing. All authors read and approved the final manuscript.

\section{Acknowledgements}

The authors wish to thank Department of Zoology and Environmental Management, University of Kelaniya for providing human and physical resources. The Sustainable Energy Authority of Sri Lanka is gratefully acknowledged for contributing funding for this study.

\section{References}

1. Pysek P, Jarosik V, Hulme PE, Pergl J, Hejda M, Schaffner U, et al. A global assessment of invasive plant impacts on resident species, communities and ecosystems: the interaction of impact measures, invading species' traits and environment. Global Change Biology. 2012;18:1725-37.

2. Abdulahi MM, Ute JA, Regasa T. Prosopis juliflora I: Distribution, impacts and available control methods in Ethiopia. Tropical and Subtropical Agroecosystems.2017; 20:75-89.

3. Zachariades C, Hoffmann JH, Roberts AP. Biological control of mesquite (Prosopis species)(Fabaceae) in South Africa. Africa Entomology. 2011; 19:40215.

4. Mwangi E, Swallow B. Prosopis juliflora invasion and rural livelihoods in the Lake Baringo area of Kenya. Conserv Soc.2008; 6:130-40.

5. Getachew S, Demissew S, Woldemariam T. Allelopathic effects of the invasive Prosopis juliflora (Sw.) DC. on selected native plant species in Middle Awash, Southern Afar Rift of Ethiopia. Manag Biol Invasions. 2012; 3: 105-14.

6. Walter KJ, Armstrong KV. Benefits, threats and potential of Prosopis in South India. For Trees Livelihoods. 2014; 23: $232-47$.

7. Perera AN, Pasiecznik NM, Smith SJ, Harris PJ, Perera ER, Premalal GC. Turning invasive Prosopis to improving livelihoods in Sri Lanka.In 17th Commonwealth Forestry Conference, Colombo, Sri Lanka 2005 Feb.

8. Bambaradeniya CN. The status and implications of alien invasive species in Sri Lanka. Zoos' Print Journal. 2002;17: 930-5.

9. Gunarathne RM ,Perera GA. Does the invasion of Prosopis juliflora cause the die-back of the native Manilkara hexandra in seasonally dry tropical forests of Sri Lanka. Tropical Ecology.2016; 57:475-88.

10. McNeely JA, editor. Global strategy on invasive alien species. IUCN; 2001.

11. Pasiecznik NM, Felker P, Harris PJ, Harsh L,Cruz G, Tewari JC, et al. The 'Prosopis Juliflora'-'Prosopis Pallida' Complex: a Monograph. Coventry: HDRA; 2001.

12. United Nations Development Programme. 2013. http://www.undp.org. Accessed 5 December 2017.

13. Subasinghe SM. Prediction of stem volume of Alstonia macrophylla growing as even-aged monocultures using diameter at breast height and total height. In Proceedings of the 15th International Forestry and Environment Symposium 2010 Nov (Vol. 26, p. 27).

14. De Alwis SA, Dayawansa PN. BIODIVERSITY BASELINE SURVEY: HORTON PLAINS NATIONAL PARK.

15. Pearson TR. Measurement guidelines for the sequestration of forest carbon. US Department of Agriculture, Forest Service, Northern Research Station; 2007.

16. Omoniyi TE, Olorunnisola AO. Experimental characterization of bagasse biomass material for energy production. International Journal of Engineering and Technology. 2014;4:582-9.

17. Smith DM. Maximum moisture content method for determining specific gravity of small wood samples. 1954. http://ir.library.oregonstate.edu/xmlui/bitstream/ handle/1957. Accessed 15 January 2018.

18. Kumar JN, Patel K, Kumar RN, Bhoi RK. An evaluation of fuelwood properties of some Aravally mountain tree and shrub species of Western India. Biomass Bioenergy. 2011; 35: 411-4. 
19. Khardiwar MS, Dubey AK, Mahalle DM, Kumar S. Study on physical and chemical properties of crop residues briquettes for gasification. International journal of renewable energy technology research.2013;2:237-248.

20. Chettri N, Sharma E. Firewood value assessment: A comparison on local preference and wood constituent properties of species from a trekking corridor, West Sikkim, India. Current Science. 2007; 1744-7. https://www.researchgate.net.

/publication/258833544_Firewood_value_assessment_A_comparison_on_local_preference_and_wood_constituent_properties_of_species_from_a_trekking Accessed 3 February 2018.

21. Rai YK, Chettri N, Sharma E. Fuelwood value index of woody tree species from Mamlay watershed in South Sikkim, India. Forests, Trees Livelihoods. 2002; 12: 209-19.

22. Ceylon Petroleum Corporation: Ceypetco Product Specifications. http://www.ceypetco.gov.lk/Ceypetco_Products.htm\#CP21(2015). Accessed 6 December 2017.

23. Bhimaya CP. A study of age and habitat differences in the fuel yield of Prosopis juliflora. Indian For. 1967; 93: 355-9. ttps://www.cabdirect.org/cabdirect/abstract/19676601138. Accessed 5 January 2018.

24. Muthana KD, Arora GD. Prosopis juliflora (Swartz) DC, a fast growing tree to bloom the desert. 1983.

25. Chavan SB, Uthappa AR, Keerthika A, Parthiban KT, Vennila S, Kumar P, et al . Suitability of Leucaena leucocephala (Lam.) de Wit as a source of pulp and fuelwood in India. J Tree Sci.2015;34:30-8. http://www.indianjournals.com/aspx?target=ijor:ts\&volume=34\&issue=1\&article=005. Accessed 25 December 2017.

26. Shanavas A, Kumar BM . Fuelwood characteristics of tree species in home gardens of Kerala, India. Agroforestry Systems. 2003; $58: 11-24$.

27. Mitchual SJ, Frimpong-Mensah K, Darkwa NA. Evaluation of Fuel Properties of Six Tropical Hardwood Timber Species for Briquettes. International Journal of Environmental and Ecological Engineering. 2015;8:531-7.

28. Kumar JIN, Patel K, Kumar RN, Bhoi RK. An assessment of Indian fuelwood with regards to properties and environmental impact. Asian Journal on Energy and Environment. 2009; 10: 99-107.

29. Oduor NM, Githiomi JK. Fuel-wood energy properties of Prosopis juliflora and Prosopis pallida grown in Baringo District, Kenya. Afr J Agric Res. 2013;8: 2476-81.

30. Groves KW, Chivuya AM. Fuelwood evaluation of four Australian-grown tree species. ACIAR Monograph. 1989; 10: $159-169$. https://www.researchgate.net/publication/303940973_Fuelwood_characteristics_of_selected_tree_species_from_Bundelkhand_region_of_Central_India. Accessed 15 January 2018.

31. Rijsdijk JF, Laming PB. Physical and related properties of 145 timbers: information for practice. Netherlands: Springer.1994.

32. Siri JKS, Udayani UJI, Kumarasinghe KDRP, Wanasinghe WMPK, Udadini KME, Bandara WARTW. Prosopis juliffora in Bundala National Park: impact on floral diversity and potential of utilizing as an alternative energy source for industries in the region. Sri Lanka: University of Kelaniya; 2015.

33. Dias DP, Marenco RA. Tree growth, wood and bark water content of 28 Amazonian tree species in response to variations in rainfall and wood density. iForest. 2016; 9: 445-51.

34. DeBell DS, Singleton R, Harrington CA, Gartner BL. Wood density and fiber length in young Populus stems: relation to clone, age, growth rate, and pruning Wood Fiber Sci. 2007; 34: 529-39.

35. Huang S, Wang BJ, Lu J, Dai C, Lei Y, Sun X. Characterizing changbai larch through veneering, part 1: effect of stand density. Bioresources. 2012; 7: 244460 .

https://www.researchgate.net/publication/271217143_Characterizing_changbai_larch_through_veneering_part_2_Effect_of_diameter_at_breast_height_an Accessed 25 April 2018.

36. Navarro M, Moya R, Chazdon R, Ortiz E, Vilchez B. Successional variation in carbon content and wood specific gravity of four tropical tree species. Bosque (Valdivia). 2013; 34:33-43.

37. Nagler PL, Shafroth PB, LaBaugh JW, Snyder KA, Scott RL, Merritt DM, et al. Saltcedar and Russian olive control demonstration act science assessment [Executive summary].2010

38. 38. Wakie TT, Hoag D, Evangelista PH, Luizza M, Laituri M. Is control through utilization a cost effective Prosopis juliflora management strategy?.J Environ Manage. 2016; 168: 74-86.

39. Walter KJ, Armstrong KV. Benefits, threats and potential of Prosopis in SouthIndia. For Trees Livelihoods. 2014; $23: 232-47$. doi:10.1080/14728028.2014.919880.

\section{Tables}

Table 1: Mean values \pm SEM of fuel wood characteristics in three DBH classes of $P$. juliflora 


\begin{tabular}{lcccccc}
\hline DBH Class & Moisture (\%) & Density & Specific gravity & Ash & Volatile Matter (\%) & Fixed \\
& & $\left(\mathrm{g} \mathrm{cm}^{-3}\right)$ & & $(\%)$ & & Carbon (\%) \\
\hline Class 1 & 30.20 & 0.92 & $0.97 \pm 0.05^{\mathrm{a}}$ & 1.72 & 77.54 & 20.47 \\
$(10 \mathrm{~cm}-19.99 \mathrm{~cm})$ & $\pm 1.10^{\mathrm{a}}$ & $\pm 0.06^{\mathrm{a}}$ & & $\pm 0.10^{\mathrm{a}}$ & $\pm 0.94^{\mathrm{b}}$ & $\pm 0.78^{\mathrm{a}}$ \\
Class 2 & 32.41 & 0.82 & 1.07 & 1.51 & 75.81 & 21.43 \\
$(20 \mathrm{~cm}-29.99 \mathrm{~cm})$ & $\pm 0.55^{\mathrm{a}}$ & $\pm 0.04^{\mathrm{a}}$ & $\pm 0.04^{\mathrm{a}}$ & $\pm 0.11^{\mathrm{a}}$ & $\pm 1.03^{\mathrm{b}}$ & $\pm 0.83^{\mathrm{a}}$ \\
Class 3 & 31.62 & 0.82 & 1.18 & 1.37 & 83.00 & 15.08 \\
$(30 \mathrm{~cm}-39.99 \mathrm{~cm})$ & $\pm 1.03^{\mathrm{a}}$ & $\pm 0.03^{\mathrm{a}}$ & $\pm 0.06^{\mathrm{a}}$ & $\pm 0.05^{\mathrm{a}}$ & $\pm 0.68^{\mathrm{a}}$ & $\pm 0.43^{\mathrm{b}}$ \\
\hline
\end{tabular}

Table 2: Measured parameters of P. juliflora in comparison with L. leucocephala

\begin{tabular}{ccc}
\hline Parameter & P. juliflora & L. leucocephala \\
\hline Moisture content (\%) & $31.56 \pm 0.87$ & $37.91 \pm 1.40$ \\
Wood density $\left(\mathrm{g} \mathrm{cm}^{-3}\right)$ & $0.84 \pm 0.03$ & $0.71 \pm 0.02$ \\
Specific gravity $\left(\mathrm{g} \mathrm{cm}^{-3}\right)$ & $1.08 \pm 0.05$ & $0.89 \pm 0.04$ \\
Ash content (\%) & $1.70 \pm 0.12$ & $1.20 \pm 0.11$ \\
Volatile matter content (\%) & $78.30 \pm 0.71$ & $84.23 \pm 1.10$ \\
Fixed carbon content (\%) & $20.00 \pm 1.11$ & $14.56 \pm 0.64$ \\
Biomass/ash ratio & $57.70 \pm 7.00$ & $62.80 \pm 8.80$ \\
Gross calorific value (GCV)(kJ kg-1) & $18.66 \pm 0.10$ & $18.35 \pm 0.18$ \\
& & \\
FVI & $3276 \pm 274$ & $3336 \pm 389$ \\
\hline
\end{tabular}

Table 3: Amount of fossil fuel replaced by $1 \mathrm{~kg}$ of P. juliflora wood compared to L. leucocephala

\begin{tabular}{|c|c|c|c|c|}
\hline Fossil Fuel & Maximum Density @ $15^{0} \mathrm{C}\left(\mathrm{kgm}^{-3}\right)$ & $\begin{array}{l}\text { Minimum Gross Calorific value } \\
\left(\mathrm{kJ} \mathrm{kg}^{-1} \text { or } \mathrm{kWh}\right)\end{array}$ & $\begin{array}{c}\text { Gross calorific value } \\
\left(\mathrm{kJ} \mathrm{kg}^{-1}\right)\end{array}$ & Amount $\left(\mathrm{L} / \mathrm{kWh}^{-1}\right)$ replaced by $1 \mathrm{~kg}$ of wood \\
\hline \multirow[t]{2}{*}{ Diesel } & 860 & 43961 & P. juliflora: 18666 & 0.50 \\
\hline & & & L.leucocephala: 18350 & 0.48 \\
\hline \multirow{2}{*}{$\begin{array}{l}\text { Furnace } \\
\text { oil }\end{array}$} & 970 & 42705 & P. juliflora: 18666 & 0.45 \\
\hline & & & L.leucocephala: 18350 & 0.43 \\
\hline \multirow[t]{2}{*}{ Electricity } & & 3600 & $P$.juliflora: 18666 & 5.18 \\
\hline & & & L.leucocephala: 18350 & 5.09 \\
\hline
\end{tabular}

\section{Figures}




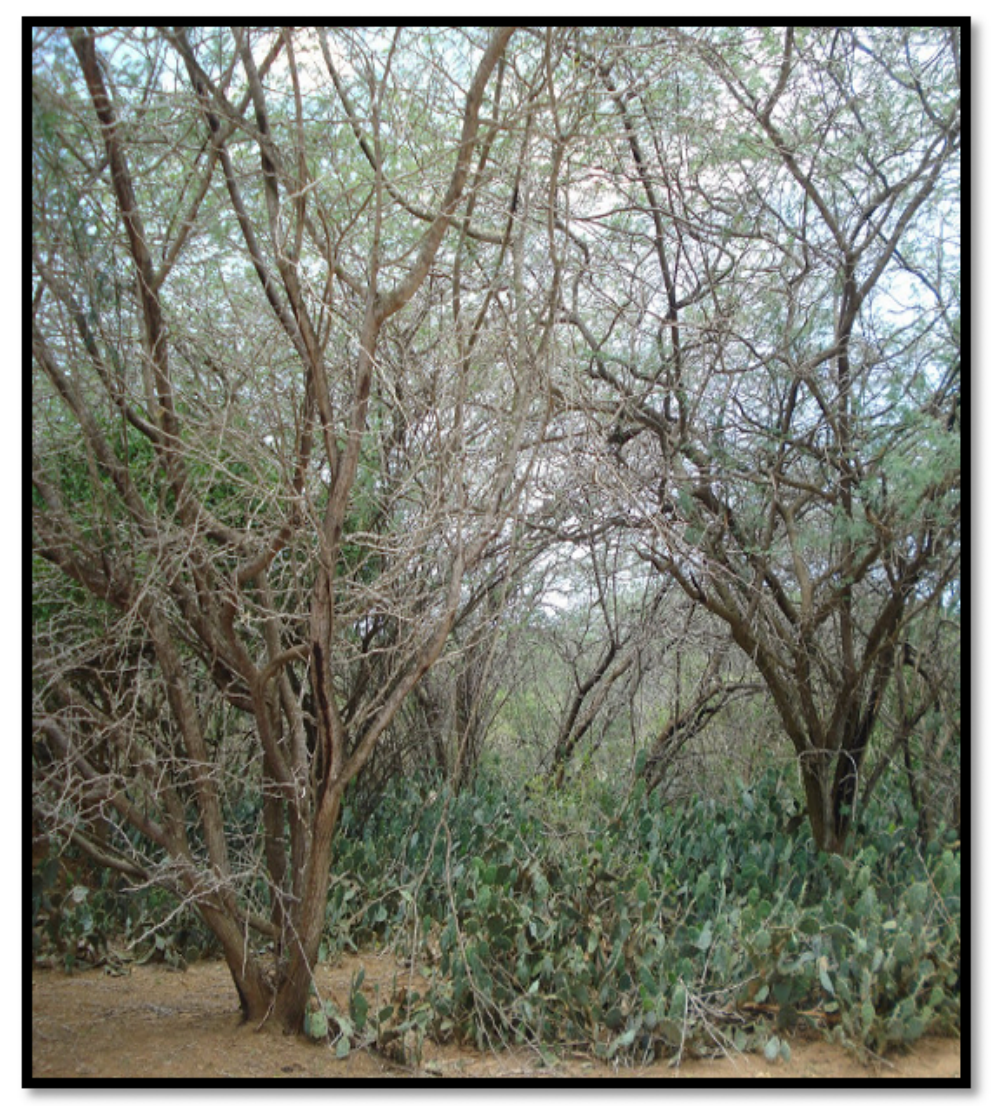

Figure 1

Mature individuals of Prosopis juliflora in the Bundala Ramsar Wetland 


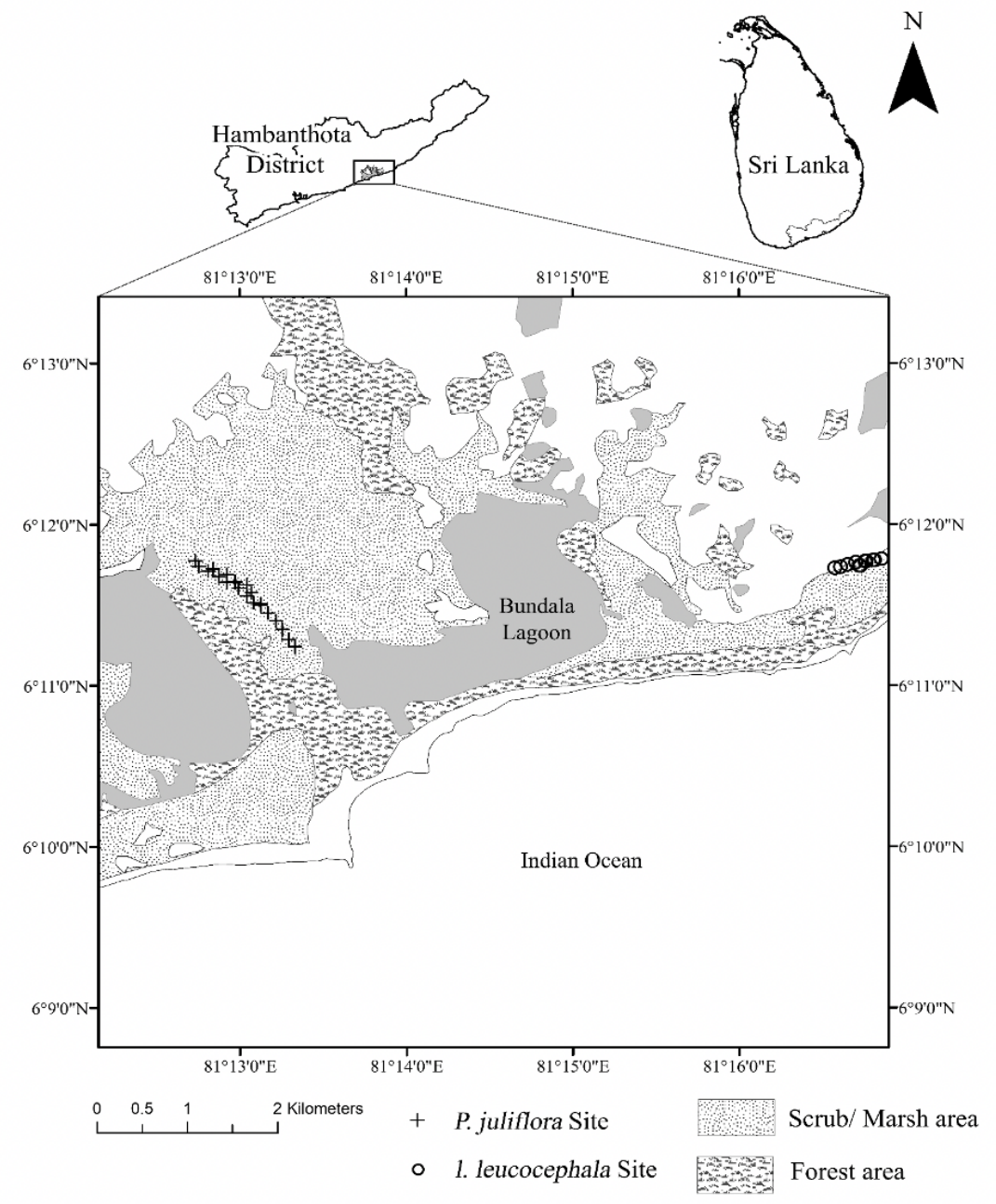

Figure 2

P. julflora abundant site (Site 1) and (L. leucocepala abundant site (Site 2) in coastal area of the Bundala Ramsar Wetland

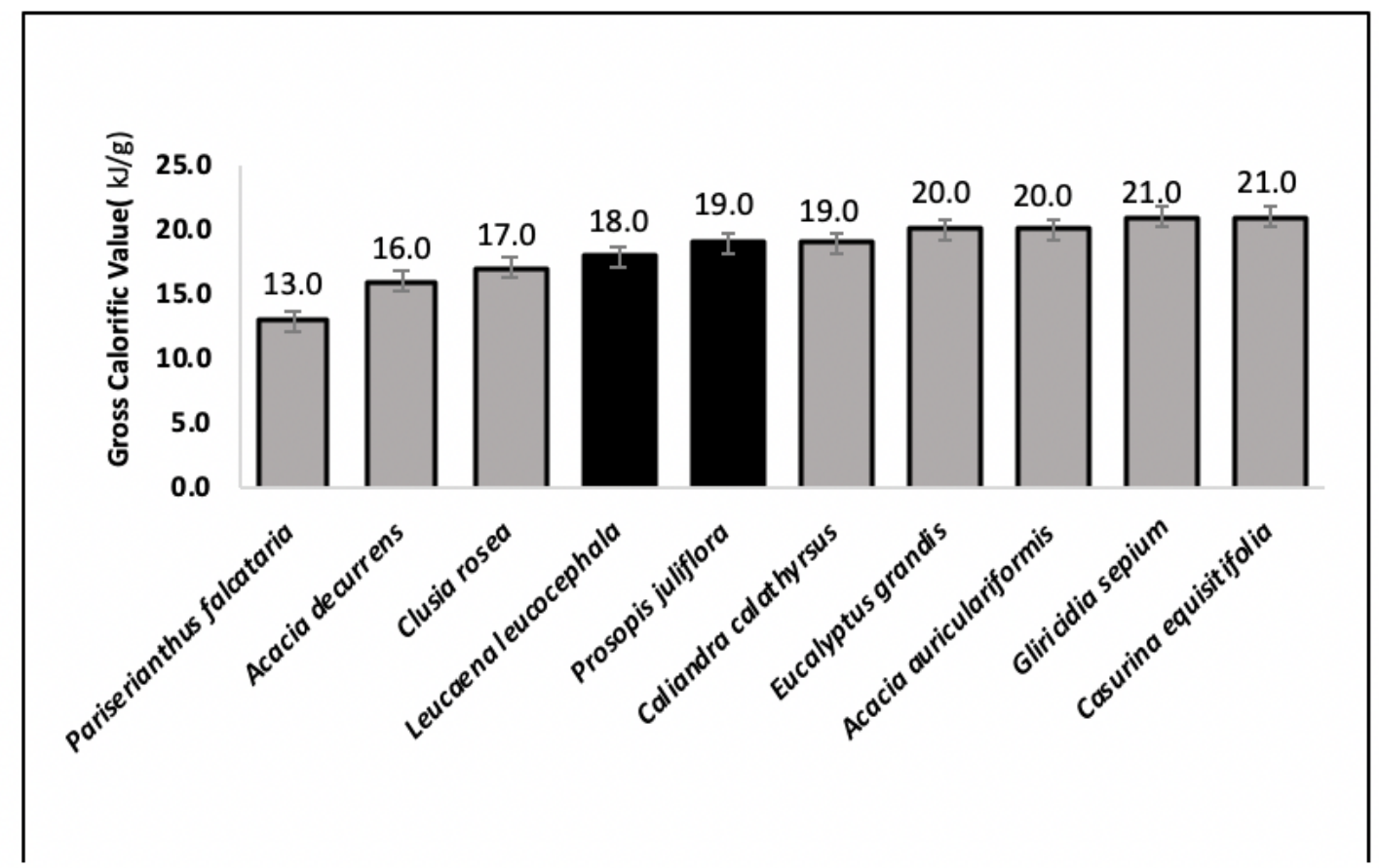

Figure 3 
Calorific vales of commonly used fuelwood species of Sri Lanka including findings of the study for two species P. juliflora and L. leucocephala (Adopted and modified from United Nations Development Programme, Promoting Sustainable Biomass Energy Production and Modern Bio-energy Technologies in Sri Lanka, Project Document, 2013)

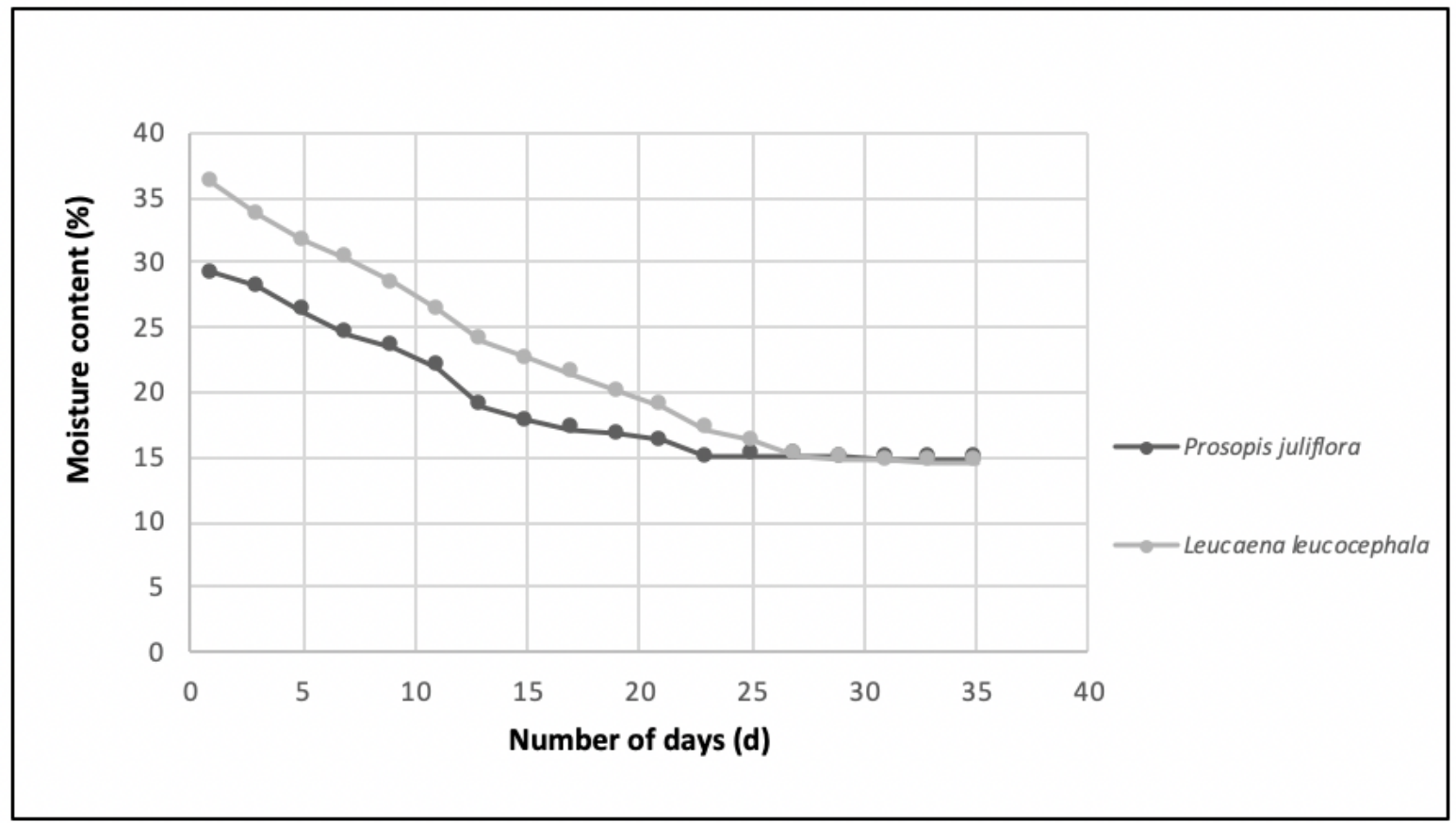

Figure 4

Variation of moisture content percentage with number of drying days for P. juliflora and L. leucocephala 